\title{
METHODS
}

\section{Designing trans-disciplinary research to support policy formulation for sustainable agricultural development}

\author{
V. Vandermeulen*, G. Van Huylenbroeck \\ Department of Agricultural Economics, Faculty of Bioscience Engineering, University of Ghent, Coupure Links 653, B-9000 Gent, Belgium
}

\section{A R T I C L E I N F O}

\section{Article history:}

Received 6 December 2007

Received in revised form

20 May 2008

Accepted 20 May 2008

Available online 24 June 2008

Keywords:

Sustainable development

Agriculture

Trans-disciplinary

System boundaries

\begin{abstract}
A B S T R A C T
The article shows how existing multidisciplinary studies on sustainable agricultural development can be joined into a trans-disciplinary approach. Three interdisciplinary projects have been combined in a participatory discussion platform, in which researchers from different disciplines (economists, ecologists, social scientist and geographers) were brought together with a variety of stakeholders. The specific application of the developed method on agricultural development in Belgium, has revealed the need for crossing system boundaries within research, articulation of definitions on sustainable development, development of a coherent sustainability labelling policy and increasing the access to nation wide data both for researchers and policy makers.
\end{abstract}

(c) 2008 Elsevier B.V. All rights reserved.

\section{Introduction}

The concept of sustainable agricultural development has been integrated into research since the declaration on sustainable development at the United Nations Conference on Environment and Development in Rio de Janeiro in 1992 (Hirsch Hadorn et al., 2006). It is an often researched topic, in the fields of agricultural science, ecological science as well as social science. Researching a topic like sustainable agricultural development is however not an easy task. Firstly, sustainable agricultural development is a complex issue (Walz et al., 2007) which can be defined as: 'the management and utilization of the agricultural ecosystem in a way that it maintains its biological diversity, productivity, regeneration capacity, vitality, and ability to function, so that it can fulfil - today and in the future- significant ecological, economic and social functions at the local, national and global levels and does not harm other ecosystems' (Lewandowski et al., 1999). Secondly, sustainable development is a socio-political model for societal changes meaning that many (different groups of) people, like citizens, farmers, industry or trade, are involved in and affected by sustainable development (Blackstock et al., 2007).

Therefore, research on sustainable agricultural development could preferably be organised in such a way that it deals with these specific characteristics (being complex and the involvement of many people). In this article it is described how trans-disciplinary research can be a good and desired approach. We define trans-disciplinary research as being a combination of interdisciplinary and participatory approaches following authors like Bruce et al. (2004), Max-Neef (2005), Hirsch Hadorn et al. (2006), Gibbons et al. (2006), Tress et al. (2007) or Uiterkamp and Vlek (2007). By being interdisciplinary, the boundaries of research disciplines are broken down and researchers are working together on the same topic in an integrated way (Bartelmus, 2000; Bruce et al., 2004). Subjects of various disciplines are integrated (e.g. economics, ecology, agronomy, technology, sociology) and different systemic perspectives are combined ranging from small systems (such

\footnotetext{
* Corresponding author. Tel.: +32 92645943; fax: +32 92646246.

E-mail address: Valerie.Vandermeulen@UGent.be (V. Vandermeulen).
} 
as the parcel or the farm) to increasingly more global levels (such as the food supply chain or the agricultural sector or region) (Klein, 2004; Huby et al., 2006). By being participatory, a dialogue is created between policy institutions and civic society in which expert knowledge is complemented by life experience of citizens and social norms (Feldmand and Westphal, 1999; Lawrence, 2004). The uncertainty due to imperfect scientific knowledge and complex processes will be addressed by 'embracing a plurality of voices, knowledge forms and values' (van den Hove, 2000; Muller, 2003; Pellizzoni, 2003). Furthermore, the research results can more easily be transformed into stable, durable and equitable implementations, because people who will be affected by sustainable agricultural development are included in the decision making (Blackstock et al., 2007).

Within this article, one method and specific application of trans-disciplinary research in the field of sustainable agricultural development is described. Within the context of Belgian agriculture, three individual research projects have been combined and clustered into a trans-disciplinary platform. It is described how a method was developed to reflect the diversity, complexity and dynamics of sustainable processes and to take the knowledge of people involved and their interests at stake into account (Hirsch Hadorn et al., 2006; Walz et al., 2007). Furthermore, it will be demonstrated that this clustering method has lead to new insights, supplementary to results of individual research actions.

\section{Material studied and methods}

This article reports on a research project, sustainable agriculture: an integrated approach for communication between scientists and stakeholders (Van Huylenbroeck et al., 2006), in which a method was developed to combine interdisciplinary research with participatory actions. In a first step, Section 2.1, three interdisciplinary research projects on sustainable agricultural development in Belgium were brought together. Out of 54 projects on the topic 'Sustainable production and consumption patterns' financed by the Belgian Science Policy ${ }^{1}$ during the period 2001-2005, the SAFE, BIO and peri-urban projects were chosen to be combined in the trans-disciplinary platform experiment. Each of these research projects was interdisciplinary and provided a foundation for trans-disciplinary research because they involve researchers from different disciplines such as economics, ecology, geography and forestry (Lawrence, 2001). In a second step, Section 2.2, participatory actions are undertaken by building a platform experiment. Such platform is created to build bridges between disciplines, between systems and between research and policy (Lawrence and Despres, 2004). The main idea of the created platform is to allow scientists, decision makers and other stakeholders to (i) share results from three projects on sustainable agriculture and generate new issues; and (ii) identify relevant sustainable development policy questions and efficient ways to address them.

\footnotetext{
${ }^{1}$ SPSD II: Scientific Support Plan for a Sustainable Development Policy - part 1: Sustainable production and consumption patterns.
}

\subsection{Three individual interdisciplinary projects on sustainable agriculture}

1. In the SAFE (Sustainability Aspects of Farming and Environment) project researchers from the agricultural, rural, environmental and systemic field built a 'framework for assessing sustainability levels in Belgian agricultural systems'. SAFE provides Belgium with a generic and holistic tool for evaluating sustainability levels (covering environmental, economic and social issues) in agricultural systems at farm level. This tool is based on creating a core list of 17 indicators, which reflect 9 sustainable objectives, and putting them into a holistic hierarchical framework of Principles, Criteria and Indicators (P,C\&I framework, see also Appendix A). The principles relate to the multiple functions of the agro-ecosystem, which go clearly beyond the production function alone and encompass the three pillars of sustainability (environmental, social and economic). Criteria are the resulting states of the agroecosystem when its related principles are respected and can be linked to the indicators. The list of indicators is the result of a standardized selection procedure that required as input the knowledge and experience of more than 25 Belgian experts. These experts listed up indicators, norms and labels on different aspects of sustainable agriculture, types of existing sustainable agricultural systems, mathematical models of sustainable agriculture and definitions of sustainable agriculture. In the final step, all selected indicators are integrated into an overall sustainability index.

In order to perform a sustainability assessment with SAFE in a farm, three things have to be done: data for the calculation of indicators has to be collected in the farm or derived from existing databases, indicators have to be calculated for the farm and these indicators have to be integrated in an overall sustainability index. This index can then be compared with sustainability indices of other farms or with reference values. So far, within the project the SAFE tool has been tested on four farms (Sauvenier et al., 2006).

2. In the BIO project on 'how can organic farming contribute to sustainable production and consumption patterns?', agricultural researchers from three Belgian universities focused on the organic production chain of beef meat. Together with field operators and beneficiaries of the research (e.g. supermarkets, farmers, wholesalers) they investigated the significantly growing organic production chain in Belgium. Until now, the sector has used production techniques borrowed from conventional cattle breeding, but these techniques often do not match neither with the requirements of organic food production nor with the consumer expectations. Using a grounded theory approach, new sustainable solutions (on environmental, social and economic components) for the sector are found. The BIO project steps aside from the 'measuring' methodology (like used in the SAFE project) and adopts a 'social learning' approach: it tries to assess the impacts on agricultural sustainability of specific and simultaneous changes at the level of the food supply chain. Intervention research was used including natural sciences, engineering 
and collective action and representatives of three supermarkets were interviewed in order to study their marketing mix and the organisation of the supply chain. Furthermore, consumers and farmers were gathered into focus groups to find out what their main problems or demands are and veterinarians were asked to state the impact of certain changes in the maintenance of cattle towards sustainability on the production chain. This all lead to the study of socio-economic impacts on the chain, sectoral impacts on the organic operators' federation and territorial impacts on the development of a local development project (Stilmant et al., 2006).

3. The peri-urban project, or the 'development of strategies for a multifunctional agriculture in peri-urban areas', investigates the functions agriculture is providing in the peri-urban zone. Researchers from the agro-economic as well as from the socio-geographic field searched for answers to questions like what kind of functions are expected from agriculture in peri-urban areas; how does agriculture currently fulfil these functions; and what can be done to improve the development of these multi-functions in terms of policy support in peri-urban zones. This project focused on the socio-economic dimension of agricultural sustainability. The research concentrated on the periurban area surrounding Brussels (the capital of Belgium) where all gradations of urbanisation (from conurbation over suburbs to residential areas) can be found. The case study also allowed to take into account the differences concerning regional policy, given that this Brussels periurban area is partly under influence of the Flemish and Walloon region. Data were collected from farmers (1106 respondents), citizens from the fringe around Brussels and from the metropolitan district of Brussels (in total 1313 respondents) as well as from the municipalities (48) on the local situation and policies by means of a postal survey. Because the sample was representative the results hold for all farms in the peri-urban region of Brussels. The com- parison of the results with other studies in other regions, for example in the Netherlands, makes it possible to draw conclusions for other urbanizing regions in Europe (Van Huylenbroeck et al., 2005).

All three research projects involved are characterized by a different approach towards sustainable development (see Table 1 for a summary of the objectives, methods, data collection, research level and application of the individual projects). Although they all recognize the existence of environmental, social and economic components within the concept of sustainable development (see Brundtland definition (World Commission on Environment and Development, 1987)), all three components are not equally developed in each of the projects. The peri-urban project e.g. focuses more on the social aspects than the other two by including citizens in the research while the BIO project includes more environmental and animal welfare concerns. Each project also has a specific objective, embedded in the more global and common goal of reaching a more sustainable agriculture. Therefore, even though each project is based on some inter-disciplinary research (by bringing together researchers from different fields), they did not completely capture the holistic aspects of sustainable agriculture and they did not consider all other stakeholders and can therefore not be categorized as trans-disciplinary.

Another problem that cannot be tackled by the individual projects is the important issue of the systemic gap of having different systems as analytical object. The SAFE project focuses on on-farm activities and measures their impact on sustainability at the level of a parcel, farm or the immediate surroundings. The peri-urban project also includes off-farm activities and involves consumers as well as producers. This research is realised in several communities put together in a peri-urban region. The BIO project includes farm activities as well as activities of other stakeholders of the food chain. It tries to evaluate the sustainability of each actor, without putting restrictions on the spatial scale.

Table 1 - The objectives, method, data collection, research level and application of the SAFE, peri-urban and BIO project

Project

\begin{tabular}{|c|c|c|c|}
\hline & SAFE & Peri-urban & $\mathrm{BIO}$ \\
\hline Main objective & Measuring agricultural sustainability & $\begin{array}{l}\text { Analysing sustainable peri-urban } \\
\text { agriculture }\end{array}$ & Building a sustainable agricultural chain \\
\hline Objectives & $\begin{array}{l}\text { To design a generic and holistic } \\
\text { tool for quantitatively evaluating } \\
\text { sustainability levels }\end{array}$ & $\begin{array}{l}\text { To examine the expectations of } \\
\text { agriculture in peri-urban areas and } \\
\text { assess if agriculture meets these } \\
\text { expectations }\end{array}$ & $\begin{array}{l}\text { To develop a research method } \\
\text { for building sustainable organic } \\
\text { production chains }\end{array}$ \\
\hline Method & $\begin{array}{l}\text { - Compiling a core list of } \\
\text { environmental, economic and } \\
\text { social indicators } \\
\text { - Collecting data at farm level to } \\
\text { calculate indicators } \\
\text { - Integrate into a sustainability index }\end{array}$ & $\begin{array}{l}\text { - Investigating the multiple functions } \\
\text { that agriculture provides or is } \\
\text { expected to provide } \\
\text { - Analysing policies to support } \\
\text { the development of multifunctional } \\
\text { agriculture }\end{array}$ & $\begin{array}{l}\text { - Characterising a production-marketing- } \\
\text { consumption chain using a set of } \\
\text { norms, standards and practices } \\
\text { - Influencing this chain by } \\
\text { modifying the relationships } \\
\text { between players }\end{array}$ \\
\hline Data collection & $\begin{array}{l}\text { Interviews with farmers Existing } \\
\text { databases }\end{array}$ & $\begin{array}{l}\text { Survey amongst farmers, citizens } \\
\text { and local policies }\end{array}$ & $\begin{array}{l}\text { Intervention-research with members } \\
\text { of the supply chain }\end{array}$ \\
\hline System boundaries & $\begin{array}{l}\text { On-farm activities of the } \\
\text { production cycle }\end{array}$ & $\begin{array}{l}\text { On- and off farm activities and } \\
\text { public demand }\end{array}$ & Food supply chain \\
\hline Spatial scale & Parcel, farm or region & peri-urban region & Country \\
\hline Application & 4 Belgian farms & Peri-urban area of Brussels & Belgian organic cattle farming \\
\hline
\end{tabular}


However the three different approaches towards sustainable development are complementary since, ideally, the objectives pursued by each one of them (i.e. sustainability of the farm, of the food supply chain and of agriculture in the peri-urban zone) should be reached in order to move towards a more sustainable agriculture. Exactly because of the complementarities in the main objectives, these three projects are combined in a covering cluster platform in order to execute trans-disciplinary research.

\subsection{Creating a trans-disciplinary platform: methodology and process}

The actual method chosen to complement the interdisciplinary research with participatory activities was based on minimizing three biases on knowledge transfer: the bias of source (distortions in a person's evaluation because of the characteristics of the person who gives the information), the bias of phrasing (distortions caused by the type of communication) and the bias of attitude (distortions based on the attitude towards the topic) (Cuppen et al., 2006). A wide range of techniques and methods can be used, like the Delphi method, citizens jury, surveys, role play, gaming, cognitive mapping or thinking outside the box (Lawrence, 2004; Cuppen et al., 2006). Within this project methods like cognitive mapping and thinking outside-the-box are used. These methods deal with the bias of phrasing and attitude and have the advantage of delivering new insights into the problem of sustainable development. In order to deal with the bias of source, a neutral professional discussion opener was provided, leading to an efficient integrated research method (Cuppen et al., 2006). The specific approach chosen was building a trans-disciplinary platform (Hoppe, 2002), based on the three individual projects, through organising three workshops (see Fig. 1) to discuss research results and possible policy implications among each other, with policy makers and the general public. The objectives of the workshops were to share results from the projects amongst researchers; discuss these results and their relevance openly to generate new/integrative insights; identify relevant sus- tainable development policy questions or problems and ways to approach or address them; explore possible implications for sustainable development policy and international adaptation; and present implications of research projects and processes.

The first workshop, on 'The role of agriculture in society and its contribution to sustainable development', lead to the understanding that there can be conflicting objectives in building sustainable agriculture indicators. In fact, sustainable development has been described, in this workshop, as an optimizing exercise, rather than maximizing, depending on moral values. Questions raised were: "what is optimal?" and "optimal to whom?". Furthermore, it was discussed whether organic or other types of sustainable agriculture is a social learning process or is about finding a new optimal system. It appears that there are three perspectives towards sustainability, three functions (economical, sociological an ecological) and different scales (sustainability at local, regional or global scale) used in the projects.

The theme for the second workshop was based on the emerging problems from the first one (Balsiger, 2004) and was called 'Building bridges from research to policy' (as can be seen in Fig. 1). The outcome of this workshop was that amongst the many challenges occurring around sustainable development the following are very important: complexity should be dealt with in a multi-level integrated way, multiple stakeholders should be involved in the process and the social dimension of sustainability should not be neglected. This implies that local level policy should be strengthened, also in rural areas and local processes for consultation should be organised. Another important aspect is to implement fully the subsidiarity principle; higher policy levels have to set targets but the local level should get some room of manoeuvre. Further, information exchange must be seen in a chain perspective and be accessible. This requires a common language and common understanding of the problems amongst different stakeholders. The need for a shared dynamic understanding of sustainable agriculture, the capability or willingness to create a common language and understanding (between actors of sustainable development and members of a project) and the need for both specialists and generalists and go between

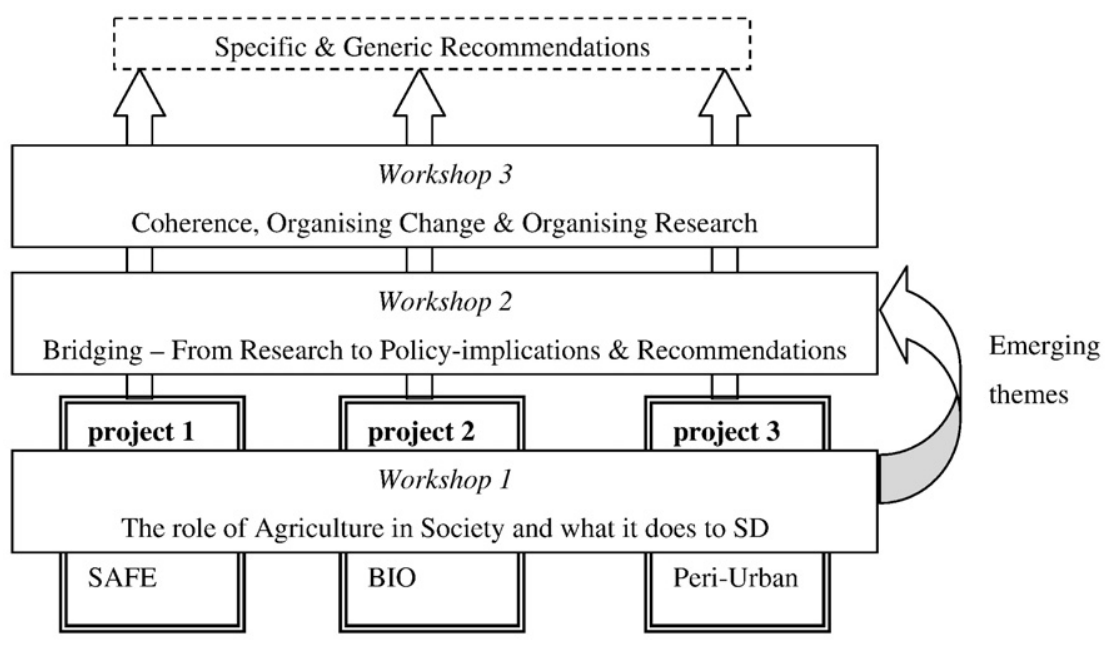

Fig. 1-Integrating three projects through three workshops. 
(someone who could switch from one issue to the other, from one level of organisation to the other) were felt to be essential required capabilities to move towards a more sustainable food production and consumption (Kingdon, 1995).

The last workshop focused on coherence, organizing change and organizing research. How can coherence be achieved between various systems? In this workshop, it was recognized that sustainable development is all about minimizing tensions (e.g. between conflicting issues), but what the tensions are depends to a large extent on who sets the goals. This will influence the notion of sustainable development, and make sustainable development a context specific and social process. To achieve the required coherence we should reflect on what should be changed and on which organising principle should be used. As an example the platform thought about the consequences of taking local food systems as the organising principle. This then raises questions such as: how to strengthen these food systems, what is the role of local action arenas and how can local policy making be strengthened?

The main aim of clustering the results, through each of the workshops, consisted of creating more adequate and detailed policy recommendations, specific and generic (see Fig. 1), by tuning research methods and integrating research activities. With this integration, economic, environmental and social policies can reinforce each other in stead of working against each other.

\section{Results and improvement of policy recommendations by trans-disciplinary action}

Each individual project had in its report launched some policy implications which should lead to a more sustainable agriculture. However, combining the results of these projects leads to considerable reconsiderations and accomplishments of some of these policy recommendations, as illustrated in Table 2.

\subsection{Crossing system boundaries on issues and scales}

As was mentioned before, each individual project has researched a part of sustainable agricultural development within well-established boundaries. However, research on sustainability can benefit from crossing these boundaries, combining economic, ecologic and social studies and being as holistic as possible in order to achieve the highest sustainable welfare now and in the future.

The first type of crossing system boundaries is minimizing tensions between conflicting issues. For example, while the SAFE project has studied reducing one type of pollution without increasing another, the peri-urban project has focused more on economic viability of a farm versus protection of its environment. Within the interdisciplinary project of SAFE, a first attempt was made to deal with these conflicts of issues by distributing weights to each indicator reflecting economic, social and environmental issues and bringing them together in one overall Sustainability Index (Van Cauwenbergh et al., 2007). The integration of indicators (and thus the attribution of weights to different issues) should however be based on a coherent vision at a higher level. Furthermore, many researchers believe that, to a certain extent, it is the responsibility of policy makers to set priorities between issues or at least to select a methodology/philosophy to do so (e.g. BanaeCosta, 1990; Mendoza and Prabhu, 2000; Pretty et al., 2000; Srdjevic et al., 2004). However, this leads to the question of institutions and tools to do so. Participatory and integrated approaches could provide such deliberative institution.

The second type of system boundaries is the limited operating scale ranging from sustainability of a farm to sustainability of the food supply chain (see Fig. 2). The possible tradeoffs between systems (e.g. sustainability of the farm vs. sustainability of the whole food-chain) have not been considered in any of the individual projects. In order to be able to make some statements on the sustainability of a development, it is

Table 2 - Short list of suggested policy recommendations based on the individual projects

The project suggests that public policy when supporting sustainable agricultural development should:

\begin{tabular}{|c|c|c|c|}
\hline SAFE & Peri-urban & $\mathrm{BIO}$ & Integrated approach \\
\hline $\begin{array}{l}\text {-Consider changes in on-farm } \\
\text { activities }\end{array}$ & $\begin{array}{l}\text {-Consider changes in on- and } \\
\text { off-farm activities and public } \\
\text { demand }\end{array}$ & $\begin{array}{l}\text { - Consider changes in the food } \\
\text { supply chain }\end{array}$ & $\begin{array}{l}\text {-Cross systemic boundaries } \\
\text { (Section 3.1) }\end{array}$ \\
\hline $\begin{array}{l}\text {-Create an agricultural } \\
\text { sustainability platform consisting } \\
\text { of a multi-disciplinary team } \\
\text {-Organize live discussions } \\
\text { between experts }\end{array}$ & $\begin{array}{l}\text {-Involve the local population in } \\
\text { the discussion about sustainable } \\
\text { agriculture } \\
\text {-Create and promote } \\
\text { local coordination centres }\end{array}$ & $\begin{array}{l}\text {-Take consumers demands for } \\
\text { products with specific quality } \\
\text { traits into account } \\
\text {-Reformulate scientific and } \\
\text { technical questions }\end{array}$ & $\begin{array}{l}\text {-Communicate on agricultural } \\
\text { sustainability (Section } 3.2 \text { ) }\end{array}$ \\
\hline $\begin{array}{l}\text {-Elaborate the integration process } \\
\text { of all indicators and decide on } \\
\text { the weight of each issue }\end{array}$ & $\begin{array}{l}\text {-Create the necessary financial } \\
\text { and policy levers to support local } \\
\text { potentiality based developments } \\
\text {-Give local products an identity } \\
\text { (chain advancement) }\end{array}$ & $\begin{array}{l}\text {-Complement normative and } \\
\text { normalising approaches }\end{array}$ & $\begin{array}{l}\text {-Create a sustainable quality } \\
\text { certification (Section } 3.3 \text { ) }\end{array}$ \\
\hline $\begin{array}{l}\text {-Use the Principles, Criteria and } \\
\text { Indicators framework to } \\
\text { assess agricultural sustainability } \\
\text {-Focus on the interrelations } \\
\text { between different sustainability } \\
\text { issues in an integrated manner }\end{array}$ & $\begin{array}{l}\text {-Include agriculture in town } \\
\text { and country planning, even in } \\
\text { an urbanising environment }\end{array}$ & $\begin{array}{l}\text {-Construct specific technical } \\
\text { references for the organic chains } \\
\text {-Stimulate the agricultural chains' } \\
\text { coherence and outfit it with a } \\
\text { reference system }\end{array}$ & -Set up standardized logbooks (3.4) \\
\hline
\end{tabular}




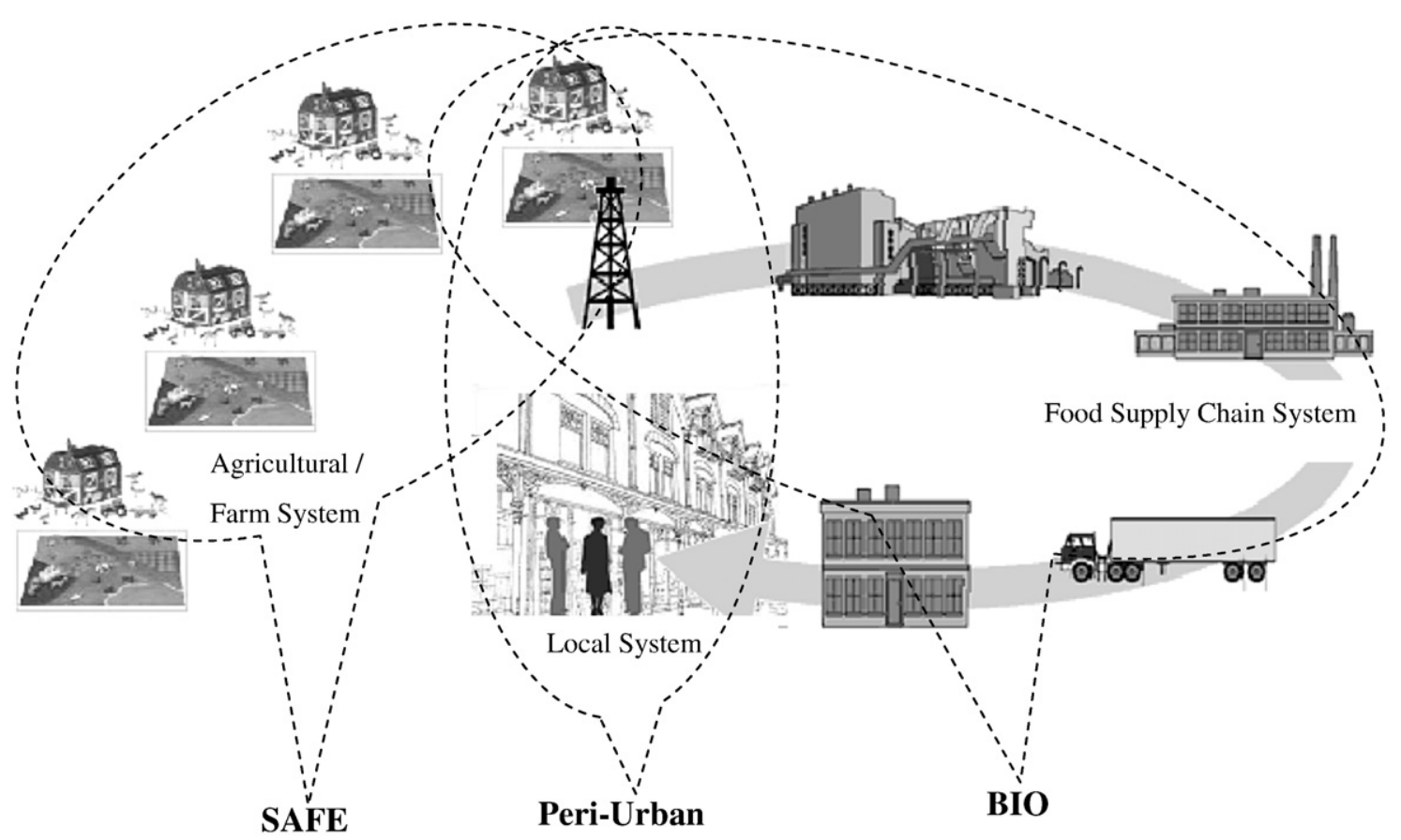

Fig. 2-System boundaries of the three individual projects.

however necessary to combine projects dealing with sustainability at a more global spatial level with those at a more systemic scale. For example, a tighter collaboration between the SAFE project on measuring sustainability and the BIO project on organic production and the food chain, can lead to the inclusion of an indicator such as 'Coherence with the sustainability of the food production chain' into the SAFE overall Sustainability Index. This would ensure that the adoption of a new and more sustainable agricultural practice in a farm does not harm the sustainability of agriculture at more global levels; and the other way around as well.

\subsection{A need to communicate on agricultural sustainability and the creation of appropriate tools to do so}

The process of integrating research projects done by scientists from different disciplines as well as the participatory approach in which other stakeholders are involved, has shown that difficulties emerge concerning communication and terminology. On the one hand, the researchers each used a separate terminology on sustainable agricultural development and on the other hand, this terminology was not always straightforward to the other stakeholders.

Successful research requires a common language (Bracken and Oughton, 2006). Even when communicating on formal knowledge is rather easy, getting the subtle aspects or differences across is hard. Each researcher has enjoyed a specific education and schooling and has made him- or herself familiar with a specific terminology. In the first workshop, it became immediately clear that this has lead to a different understanding on sustainable development. For example, researchers from the BIO project looked at sustainability as a social process which cannot be divided into subcategories while researchers from the SAFE project looked at sustainability using a more mathematical approach as being the sum of different problems. After a discussion on this during the platform workshop it was acknowledged that sustainable development and many other key words entail different meanings and that it is therefore important to clearly state what researchers are talking about.

Solving communication problems is not only important between researchers, but also between research and the public or policy makers. When integrating the results of the projects, an agreement on the necessity for public administration was found to improve the information shared with members of our society (citizens, consumers, producers, policy makers, etc.) on the actual meaning of sustainable development and, more specifically, agricultural sustainability. Suitable campaigns with appropriate communication tools could help to transfer this uniform terminology to the public. For example, the SAFE project, by discussing the results of the sustainability assessment in a farm with the farmer, appeared to offer a sound and efficient communication tool. However, in the current form, the framework alone is too abstract and does not speak enough to farmers, also because it lacks coherence with the higher levels (see before). It was acknowledged that this remains a weakness and problem.

\subsection{Creation of a 'sustainable quality certification label'}

When looking at the results of the peri-urban project, it seems that there exists a demand from citizens to have agriculture and agricultural products nearby. However, this attitude is not often translated into changed behaviour. One of the reasons for this might be that consumers and citizens do not reflect on the sustainable character of the good or service they utilize. In the organic food sector, this problem has been, partly, solved by labelling products, through which it can be made more 
obvious to end users as well as to processors that they are using sustainable products (BIO project). The peri-urban project furthermore shows that a label linked to the production place can be useful because the values of consumers tend to differ according to the territory (Boulanger et al., 2004). However, other agricultural labels have not been very successful in general, partly because they are too numerous (Ilbery and Maye, 2007) and not well known by consumers.

In order to develop efficient labels that might contribute to the awareness of consumers as well as producers on sustainable agricultural production, two problems should be solved. The first problem is the appropriate scale for such a label. Should it be local so that each administrative region can develop its own label with its own standards and thus its own significance; or should it be more global as to create a standardized label at the European level. As was mentioned earlier to solve this question, it is necessary to reflect on system boundaries influencing the incentive structure of stakeholders (in this case consumers and producers). Second, there might be a problem of production standards as there may be exclusion effects (e.g. small farmers that are not able to invest to follow a standard leading to undesired scale increases at landscape or business level). The creation of a 'sustainability quality certification' label therefore could be based not only on an indicator project such as SAFE but could also take into account results of effects at other boundary levels, such as illustrated in the BIO-project (effects on other stakeholders in the organic production chain) or in the periurban project (effects at regional level).

\subsection{Accessible information}

Each project has used its own method in collecting data (see Table 1): conducting surveys amongst farmers and consumers (like in the peri-urban project), organising personal interviews with all actors in the chain (like in the BIO project) or collecting data from existing data bases (like in the SAFE project). Each project encountered similar problems with limited or unreliable data with respect to production or consumption. Furthermore, there appears to be a need for a data system enabling to perform analysis at different scale levels. For example, correctly aggregated farm or consumer data at municipal level might enable the analysis of effects of differences in local policies as applied in the peri-urban project (see Vandermeulen et al., 2006) or might help to calculate e.g. sustainability indexes for a food chain.

\section{Conclusion and discussion}

Disciplinary research has the advantage of being very specific, specialised and detailed. It combines the views of experts in the same field and gives elaborate answers to specific questions. However, in research on complex real issues, it is often necessary to combine knowledge on different subjects and expert views from different disciplines. Especially in the case of research on sustainability issues, where problems in economics, ecology and sociology have to be tackled simultaneously, disciplinary research often fails to describe the whole picture. Therefore, it is suggested to use interdisciplinary research methods in which different disciplines are not only comparing results but are working with one common meth- odology towards finding solutions for complicated issues. An attempt was made to build such an approach in an experiment involving three research projects financed by Federal Science Policy in Belgium. As illustrated, although each project might have resulted in useful policy recommendations at its own level, combining this expertise from different projects and discussing the results with other stakeholders shows that some other issues, problems or questions are raised which would not have been defined by the individual (although interdisciplinary) projects. Looking at the same problems from different systemic perspectives and scales resulted in supplementary policy recommendations. Also the incorporation of stakeholders, and therefore the adoption of a participatory approach, in the discussions was felt to be useful. The advantage of involving stakeholders is that they are able to reflect the consequences on their own situation which might help to clarify why certain things do not develop as 'scientific' models predict or suggest. For example, confronting the results of the peri-urban project with consumers organisations helped to explain why citizens claim to be concerned about sustainability, but do not consume sustainable products (for example because of the lack of clear labelling making translation of attitude in behaviour not easy). Furthermore, if research has to be implemented through policy actions, involving stakeholders in the primary research might stimulate them to actually participate when policy actions are carried out.

The article shows how a trans-disciplinary research platform can be built in which results of different but linked research projects are discussed, between researchers and with stakeholders. It shows how trans-disciplinary research can lead to the discovery of problems and issues that are not dealt with in multidisciplinary research. A step further would be to build the trans-disciplinary research steps in the original research conception. In this way, trans-disciplinary research might be able to create new knowledge and insights, solutions for the many raised questions, as advocated by Lawrence and Despres (2004). However, this would require another research configuration (interdisciplinary research institutes) and different research funding rules and output measuring institutions (away from the mono-disciplinary citation indices). Although our experiment is only a minor step forward from interdisciplinary to trans-disciplinary research, it suggests that a repetition or generalisation of such an approach could lead to more comprehensive and holistic policy recommendations and might convince research funding agencies about the usefulness of real trans-disciplinary approaches.

\section{Acknowledgments}

This article is based on the results of a research project financed by the Belgian Science Policy in the framework of a Scientific Support Plan for a Sustainable Development Policy — part 1: Sustainable production and Consumption. The project is called: 'Sustainable agriculture: an integrated approach for communication between scientists and stakeholders' and was executed in 2006 by Van Huylenbroeck, G. and Vandermeulen, V. of the University of Gent; Van Hecke, E., Meert, H., Muys, B., Mathijs, E. and Hermy, M. of the University of Leuven; Peeters, A., Vanclooster, M., Bielders, C., Sauvenier, X. of the University of 
Louvain la Neuve; Mormont, M. of the University of Liège and Stilmant, D. of the Walloon Centre of Agronomic Research. More information on the results of the three individual projects can be found on the website of the Belgian Science Policy (www. belspo.be) (Van Huylenbroeck et al., 2005; Sauvenier et al., 2006; Stilmant et al., 2006).

Appendix A. The 'Safe Principles, Criteria \& Indicators ( $P, C \& I)$ framework' (Van Cauwenbergh et al., submitted for publication)

\begin{tabular}{|c|c|}
\hline Principles & Criteria \\
\hline \multicolumn{2}{|l|}{ Environmental pillar } \\
\hline \multicolumn{2}{|l|}{ Ecosystem component } \\
\hline \multicolumn{2}{|l|}{ Air } \\
\hline $\begin{array}{l}\text { Supply of quality air } \\
\text { function of the }\end{array}$ & $\begin{array}{l}\text { Greenhouse gases emission } \\
\text { is minimized }\end{array}$ \\
\hline agro-ecosystem & Acidifying and eutrophying \\
\hline $\begin{array}{l}\text { shall be maintained } \\
\text { or enhanced }\end{array}$ & $\begin{array}{l}\text { pollutants emission is } \\
\text { minimized }\end{array}$ \\
\hline & $\begin{array}{l}\text { Ecotoxic pollutants } \\
\text { emission is minimized }\end{array}$ \\
\hline $\begin{array}{l}\text { Air buffering function of } \\
\text { the agro-ecosystem shall } \\
\text { be maintained or enhanced }\end{array}$ & $\begin{array}{l}\text { Wind speed is adequately } \\
\text { buffered }\end{array}$ \\
\hline \multicolumn{2}{|l|}{ Soil } \\
\hline $\begin{array}{l}\text { Soil regulation function of } \\
\text { the agro-ecosystem shall } \\
\text { be maintained or enhanced }\end{array}$ & $\begin{array}{l}\text { Soil loss is minimized } \\
\text { Soil chemical quality is } \\
\text { maintained or increased } \\
\text { Soil physical quality is } \\
\text { maintained or increased }\end{array}$ \\
\hline \multicolumn{2}{|l|}{ Water } \\
\hline $\begin{array}{l}\text { Supply of water function } \\
\text { of the agro-ecosystem shall }\end{array}$ & $\begin{array}{l}\text { Adequate amount of surface } \\
\text { water is supplied }\end{array}$ \\
\hline be maintained or enhanced & $\begin{array}{l}\text { Adequate amount of soil } \\
\text { moisture is supplied } \\
\text { Adequate amount of ground } \\
\text { water is supplied }\end{array}$ \\
\hline $\begin{array}{l}\text { Supply of quality water } \\
\text { function of the }\end{array}$ & $\begin{array}{l}\text { Surface water of adequate } \\
\text { quality is supplied }\end{array}$ \\
\hline $\begin{array}{l}\text { agro-ecosystem shall be } \\
\text { maintained or enhanced }\end{array}$ & $\begin{array}{l}\text { Soil water of adequate quality } \\
\text { is supplied }\end{array}$ \\
\hline & $\begin{array}{l}\text { Groundwater of adequate } \\
\text { quality is supplied }\end{array}$ \\
\hline $\begin{array}{l}\text { Water buffering function of } \\
\text { the agro-ecosystem shall } \\
\text { be maintained or enhanced }\end{array}$ & $\begin{array}{l}\text { Flooding and runoff regulation } \\
\text { is maintained or enhanced }\end{array}$ \\
\hline \multicolumn{2}{|l|}{ Energy } \\
\hline $\begin{array}{l}\text { Supply of exergy function of } \\
\text { the agro-ecosystem shall } \\
\text { be maintained or enhanced }\end{array}$ & $\begin{array}{l}\text { Adequate amount of exergy is } \\
\text { supplied }\end{array}$ \\
\hline $\begin{array}{l}\text { Energy flow buffering function } \\
\text { of the agro-ecosystem shall } \\
\text { be maintained or enhanced }\end{array}$ & $\begin{array}{l}\text { Energy flow is adequately } \\
\text { buffered }\end{array}$ \\
\hline \multicolumn{2}{|l|}{ Biodiversity } \\
\hline $\begin{array}{l}\text { Supply of biotic resources } \\
\text { function of the } \\
\text { agro-ecosystem shall be } \\
\text { maintained or enhanced }\end{array}$ & $\begin{array}{l}\text { Planned biodiversity is } \\
\text { maintained or increased } \\
\text { Natural/spontaneous } \\
\text { biodiversity is maintained } \\
\text { or increased }\end{array}$ \\
\hline
\end{tabular}

Appendix A (continued)

\begin{tabular}{ll}
\hline Principles & \multicolumn{1}{c}{ Criteria } \\
\hline $\begin{array}{l}\text { Biodiversity } \\
\text { Supply of habitat function } \\
\text { of the agro-ecosystem shall } \\
\text { be maintained or enhanced }\end{array}$ & $\begin{array}{l}\text { Diversity of habitats is } \\
\text { maintained or increased }\end{array}$ \\
$\begin{array}{l}\text { Supply of quality habitat function } \\
\text { of the agro-ecosystem shall }\end{array}$ & $\begin{array}{l}\text { Functional quality of habitats } \\
\text { be maintained or enhanced }\end{array}$
\end{tabular}

Ecosystem integrity

Ecosystem stability regulation function shall be maintained or enhanced

Resistance of the ecosystem is maintained or increased Resilience of the ecosystem is maintained or increased

Economic pillar

Viability

Economic function of the agro-ecosystem shall be maintained or enhanced

Farm income is ensured Dependency on direct and indirect subsidies is minimized Dependency on external finance is optimal Agricultural activities are economically efficient Agricultural activities are technically efficient Market activities are optimal Farmer's professional training is optimal Inter-generational continuation of farming activity is ensured Land assessment issue!

Social pillar

Food security and safety Production function of the agro-ecosystem shall be maintained or enhanced

Quality of life Physical well-being of the farming community function of the agro-ecosystem shall be maintained or enhanced Psychological well-being of the farming community function of the agro-ecosystem shall be maintained or enhanced
Production capacity is compatible with society's demand for food Quality of food and raw materials is increased Diversity of food and raw materials is increased Adequate amount of agricultural land is maintained

Labour conditions are optimal Health of the farming community is acceptable

Education of farmers and farm workers is optimal Equality in the man-woman relation is acceptable Family access to and use of social infrastructures and services is acceptable Family access to and participation in local activities is acceptable Family integration in the society is acceptable Farmer's feeling of independence is satisfactory 


\begin{tabular}{|c|c|}
\hline Principles & Criteria \\
\hline $\begin{array}{l}\text { Social acceptability } \\
\text { Well-being of the society } \\
\text { function of the agro-ecosystem } \\
\text { shall be maintained or enhanced }\end{array}$ & $\begin{array}{l}\text { Amenities are maintained or } \\
\text { increased } \\
\text { Pollution levels are reduced } \\
\text { Production methods are } \\
\text { acceptable } \\
\text { Quality taste of food is } \\
\text { increased } \\
\text { Equity is maintained or } \\
\text { increased } \\
\text { Stakeholder involvement is } \\
\text { maintained or increased }\end{array}$ \\
\hline $\begin{array}{l}\text { Cultural acceptability } \\
\text { Information function of the } \\
\text { agro-ecosystem shall be } \\
\text { maintained or enhanced }\end{array}$ & $\begin{array}{l}\text { Educational value features are } \\
\text { maintained or increased } \\
\text { Scientific value features are } \\
\text { maintained or increased } \\
\text { Cultural heritage value } \\
\text { features are maintained or } \\
\text { increased } \\
\text { Spiritual heritage value } \\
\text { features are maintained or } \\
\text { increased }\end{array}$ \\
\hline
\end{tabular}

\section{R E F E R E N C E S}

Balsiger, P.W., 2004. Supradisciplinary research practices: history, objectives and rationale. Futures 36, 407-421.

BanaeCosta, C. (Ed.), 1990. Readings in Multiple Criteria Decision Aid. Springer, Berlin.

Bartelmus, P., 2000. Sustainable development: paradigm or paranoia? International Journal of Sustainable Development 3 (4), 358-369.

Blackstock, K.L., Kelly, G.J., Horsey, B.L., 2007. Developing and applying a framework to evaluate participatory research for sustainability. Ecological Economics 60, 726-742.

Boulanger, A., Meert, H., Van Hecke, E., 2004. The societal demand for public goods in peri-urban areas: a case from the Brussels urban region. EAAE Seminar, Multifunctional agriculture, policies and markets: Understanding the critical linkages. Diffusion scientifique Agrocampus Rennes, Rennes, 1. 144-158 pp.

Bracken, L.J., Oughton, E.A., 2006. 'What do you mean?' The importance of language in developing interdisciplinary research. Transactions of the Institute of British Geographers 31, 371-382.

Bruce, A., Lyall, C., Tait, J., Williams, R., 2004. Interdisciplinary integration in Europe: the case of the Fifth Framework programme. Futures 36 (4), 457-470 (May).

Cuppen, E., Hisschemöller, M., Midden, C., 2006. Introducing a framework for evaluating the quality of methods to facilitate participatory assessments. Participatory Approaches in Science and Technology, Edinburgh, Scotland. $12 \mathrm{pp}$.

Feldmand, R., Westphal, L., 1999. Participatory design in support of empowerment: the greening of a public housing development. Places 12, 34-37.

Gibbons, M., Limoges, C., Nowotny, H., Schartzman, S., Scott, P., Trow, M. (Eds.), 2006. The New Production of Knowledge: The Dynamics of Science and Research in Contemporary Societies. Sage Publications, London. 180 pp.

Hirsch Hadorn, G., Bradley, D., Pohl, C., Rist, S., Wiesmann, U., 2006. Implications of transdisciplinarity for sustainability research. Ecological Economics 60, 119-128 (Nov.).
Hoppe, R., 2002. Rethinking the puzzles of science-policy nexus: boundary traffic, boundary work and the mutual transgression between STS and policy studies. EASST conference, York, Great Britain.

Huby, M., Cinderby, S., Crowe, A.M., Gillings, S., McClean, C.J., Moran, D., Owen, A., White, P.C.L., 2006. The association of natural, social and economic factors with bird species richness in rural England. Journal of Agricultural Economics 57, 295-312.

Ilbery, B., Maye, D., 2007. Marketing sustainable food production in Europe: case study evidence from two Dutch labelling schemes. Tijdschrift voor Economische en Sociale Geografie 98, 507-518.

Kingdon, J.W. (Ed.), 1995. Agendas, Alternatives, and Public Policies. Harper Collins, New York. 280 pp.

Klein, J.T., 2004. Interdisciplinarity and complexity: an evolving relationship. Emergence, Complexity and Organization 6, 2-10.

Lawrence, R.J., 2001. Human ecology (Tolba, M.Tolba, M.s) In: Tolba, M. (Ed.), Our Fragile World: Challenges and Opportunities for Sustainable Development. EOLSS Publishers, Oxford, pp. 675-693.

Lawrence, R.J., 2004. Housing and health: from interdisciplinary principles to transdisciplinary research and practice. Futures 36, 487-502.

Lawrence, R.J., Despres, C., 2004. Futures of transdisciplinarity. Futures 36, 397-405.

Lewandowski, I., Härdtlein, M., Kaltschmitt, M., 1999. Sustainable crop production: definition and methodological approach for assessing and implementing sustainability. Crop Science 39, 184-193.

Max-Neef, M.A., 2005. Foundations of transdisciplinarity. Ecological Economics 53, 5-16.

Mendoza, G., Prabhu, R., 2000. Multiple criteria decision making approaches to assessing forest sustainability using criteria and indicators: a case study. Forest Ecology and Management 131, 107-126.

Muller, A., 2003. A flower in full blossom? Ecological economics at the crossroads between normal and post-normal science. Ecological Economics 45, 19-27.

Pellizzoni, L., 2003. Uncertainty and participatory democracy. Environmental Values 12, 195-224.

Pretty, J.N., Brett, C., Gee, D., Hine, R.E., Mason, C.F., Morison, J.I.L., Raven, H., Rayment, M.D., van der Bijl, G., 2000. An assessment of the total external costs of the UK agriculture. Agricultural Systems 65, 113-136.

Sauvenier, X., Valckx, J., Van Cauwenbergh, N., Wauters, E., Bachev, H., Biala, K.B.C., Brouckaert, V., Garcia-Cidad, V., Goyens, S., Hermy, M., Mathijs, E., Muys, B., Vanclooster, M., Peeters, A., 2006. Framework for assessing sustainability levels in Belgian agricultural systems - SAFE. In: Federal Science Policy (Ed.), Final Reports, Brussels. 126 pp.

Srdjevic, B., Medeiros, Y., Faria, A., 2004. An objective multi-criteria evaluation of water management scenarios. Water Resources Management 18, 35-54.

Stilmant, D., Van Huylenbroeck, G., Mormont, M., 2006. How can organic farming contribute to sustainable production and consumption patterns? In: Belgian Science Policy (Ed.), Final Reports, Brussels.

Tress, G., Tress, B., Fry, G., 2007. Analysis of the barriers to integration in landscape research projects. Land Use Policy 24, 374-385.

Uiterkamp, A., Vlek, C., 2007. Practice and outcomes of multidisciplinary research for environmental sustainability. Journal of Social Issues 63, 175-197.

Van Cauwenbergh, N., Biala, K., Bielders, C., Brouckaert, V., Franchois, L., Garcia Cidad, V., Hermy, M., Mathijs, E., Muys, B., Reijnders, J., Sauvenier, X., Valckx, J., Vanclooster, M., Van der Veken, B., Wauters, E., Peeters, A., 2007. SAFE - a hierarchical framework for assessing the sustainability of agricultural systems. Agriculture, Ecosystems \& Environment 120, 229-242. 
Van Cauwenbergh, N., Biala, K., Brouckaert, V., Franchois, L., Garcia-Cidad, V., Reijnders, J., Sauvenier, X., Valckx, J., Van der Vaken, B., Wauters, E., Bielders, C., Hermy, M., Mathijs, E., Muys, B., Vanclooster, M., Peeters, A., submitted for pulication. SAFE Framework for assessing sustainability levels in Belgian agricultural systems: I Hierarchical framework. Agriculture, Ecosystems and Environment.

van den Hove, S., 2000. Participatory approaches to environmental policy-making: the European Commission Climate Policy Process as a case study. Ecological Economics 33, 457-472.

Van Huylenbroeck, G., Van Hecke, E., Meert, H., 2005. Development Strategies for a Multifunctional Agriculture in peri-urban areas. In: Policy, F.S. (Ed.), Final Reports, Brussels. 161 pp.

Van Huylenbroeck, G., Van Hecke, E., Meert, H., Vandermeulen, V., Peeters, A., Muys, B., Mathijs, E., Hermy, M., Vanclooster, M.,
Bielders, C., Sauvenier, X., Mormont, M., Stilmant, D. (Eds.), 2006. Sustainable Agriculture: an Integrated Approach for Communication Between Scientists and Stakeholders, Brussel. Vandermeulen, V., Verspecht, A., Van Huylenbroeck, G., Meert, H., Boulanger, A., Van Hecke, E., 2006. The importance of the institutional environment on multifunctional farming systems in the peri-urban area of Brussels. Land Use Policy 486-501.

Walz, A., Lardelli, C., Behrendt, H., Gret-Regamey, A., Lundstrom, C., Kytzia, S., Bebi, P., 2007. Participatory scenario analysis for integrated regional modelling. Landscape and Urban Planning 81, 114-131.

World Commission on Environment and Development, 1987. Brundtland Report. 